\title{
Adam Samborski*
}

\section{ZŁOŻONOŚĆ WYBORU W DECYZJACH INWESTYCYJNYCH}

\section{WPROWADZENIE}

We wszystkich systemach emerytalnych podstawowe pytania dotyczą kwestii wyborów dokonywanych przez podmioty indywidualne. Najistotniejsze dotyczą tego, czy i w jakim zakresie jednostki powinny decydować o: wyborze usługodawcy oferującego produkty emerytalne; wyborze portfela inwestycyjnego; czy też o wyborze strumienia dochodów na emeryturze. Rozważania w niniejszym tekście koncentrują się na indywidualnych decyzjach emerytalnych, które podejmowane są w fazie akumulacji kapitału. Przedmiotem dociekań stają się pytania: (1) o przyczyny małego zainteresowania oszczędzaniem w ramach trzeciego filaru zabezpieczenia emerytalnego, (2) o przyczyny zróżnicowania oszczędzających zależne od płci i wieku, (3) oraz pytanie o przyczyny determinujące alokację aktywów w ramach IKE PZU.

W tekście dokonano analizy podstawowych rozwiązań prawnych regulujących zasady funkcjonowania indywidualnych kont emerytalnych oraz indywidualnych kont zabezpieczenia emerytalnego, jak również podstawowych wielkości statystycznych opisujących ten rynek. Zwrócono uwagę na kluczowe bariery rozwoju i omówiono zachowania inwestycyjne oszczędzających w ramach indywidualnych kont emerytalnych. Tekst kończą propozycje mające na celu pobudzenie rozwoju dobrowolnych form zabezpieczenia emerytalnego.

\section{ZACHOWANIA ZWIĄZANE Z WYBORAMI INWESTYCYJNYMI}

$\mathrm{Na}$ gruncie literatury anglojęzycznej problematyka złożoności wyboru w decyzjach emerytalnych jest szeroko omawiana w odniesieniu do doświad-

\footnotetext{
* Prof. UE dr hab., Uniwersytet Ekonomiczny w Katowicach.
} 
czeń krajów wysoko rozwiniętych. Stosunkowo jednak niewiele miejsca poświęca tej tematyce literatura krajowa. Ciekawego przeglądu zachowań inwestycyjnych w tym obszarze dokonali Tapia i Yermo ${ }^{1}$ oraz Collard ${ }^{2}$. Wskazali oni na szereg barier i wyzwań ograniczających racjonalność podejmowanych decyzji inwestycyjnych. Tapia i Yermo wyodrębnili sześć głównych czynników ograniczających racjonalność, powszechnie akceptowanych i często cytowanych w literaturze wyboru inwestycji, takich jak: wybór i przeciążenie informacją, niestabilne lub nieokreślony preferencje, heurystyki w podejmowaniu decyzji (stosowanie skrótów i reguł kciuka), ,efekt ramki" a układ menu inwestycyjnego, opieszałość i inercja, zbytnia pewność siebie. Collard do czynników tych dodała brak zrozumienia i wiedzy konsumenta o emeryturach i wyborze inwestycji. Czynniki ograniczające racjonalność wyboru w decyzjach emerytalnych, zdaniem Tapia i Yermo oraz Collard, obejmują więc:

- wybór i przeciążenie informacją: w wielu badaniach podejmuje się problematykę wpływu liczby ofert inwestycyjnych na zachowania inwestorów. Wbrew powszechnemu przekonaniu, większy wybór (wachlarz inwestycyjny oferty) nie zawsze jest lepszy. Inwestorzy przeciążeni różnorodnością opcji wyboru, często nie podejmują żadnego działania. Wyniki badań wskazują, że zbyt wiele możliwości inwestycyjnych związana jest $\mathrm{z}$ nadmiarem informacji, co prowadzi do większego wykorzystania opcji domyślnej, a nawet spadku wskaźnika uczestnictwa. Nadmiar wyboru ma również wpływ na alokację aktywów. Podmioty indywidualne ograniczają zaangażowanie w akcje, wraz ze wzrostem opcji inwestycyjnych w funduszu emerytalnym;

- niestabilne i nieokreślone preferencje - pomimo tego, że członkowie planu dostrzegają potrzebę maksymalizacji dochodów emerytalnych, problem niespójnych preferencji w podejmowaniu decyzji inwestycyjnych komplikuje optymalny układ planu emerytalnego. Wyniki wielu badań w tym obszarze wskazują na to, że osoby indywidualne często nie docierają do decyzji dotyczących preferowanych firm. Indywidualne preferencje dotyczą raczej ryzyka i czasu, na przykład, zmieniają się w zależności od podejmowanych decyzji;

- heurystyki w podejmowaniu decyzji - innymi czynnikami podważającymi racjonalność w decyzjach inwestycyjnych są skróty lub „heurystyki”. Heurystyki są to proste zasady kciuka, które zostały zaproponowane, aby wyjaśnić, w jaki sposób ludzie podejmują decyzje dotyczące osądów i rozwiązywania problemów w obliczu złożonych spraw problemów lub niepełnych informacji. Inwestorzy codziennie mają do czynienia z dużą ilością informacji, które powinny umożliwić im podejmowanie świadomych i ekonomicznie racjonalnych de-

${ }^{1}$ W. T a pi a, J. Y er mo, Implications of Behavioural Economics for Mandatory Individual Account Pension Systems, OECD Working Papers on Insurance and Private Pensions, no. 11, OECD Publishing, Paris 2007.

${ }^{2}$ S. Colla rd, Individual investment behaviour: A brief review of research, Personal Finance Research Centre. Final report, University of Bristol, Bristol 2009. 
cyzji. Proces podejmowania decyzji, nie jest jednak ściśle racjonalny, w którym wszystkie istotne informacje są zbierane i obiektywnie oceniane. Decydent raczej stosuje psychologiczne skróty, które nie zawsze prowadzą do racjonalnych decyzji;

- ,efekt ramki” a układ menu inwestycyjnego - tego typu odchylenia od racjonalności $\mathrm{w}$ procesie podejmowaniu decyzji, wynikają $\mathrm{z}$ faktu, że wielu uczestników procesów decyzyjnych łatwo ulega wpływom sposobu, w jaki prezentowane są kwestie dotyczące oszczędności i inwestycji - tj. w jaki sposób są one dla nich „oprawione”. Jeśli prezentowana jest pewna liczba różnych opcji inwestycyjnych, wpływ na dokonanie wyboru mają zagadnienia, takie jak numeracja, kolejność i układ w jakim występują;

- opieszałość i inercja - istotnym czynnikiem behawioralnym wpływającym na aktywne decyzje inwestycyjne, są opieszałość i inercja. W przypadku, gdy członek planu emerytalnego ma zmierzyć się ze złożonymi decyzjami, dotyczącymi wyboru inwestycji, inercja (zachować wszystko tak jak jest) lub opieszałość (odłożyć decyzję do jutra) wpływają na ich decyzje, prowadzące do wyborów sub-optymalnych. Wybory sub-optymalne (tj. wybory mniej korzystne i mniej pożądane) mogą nie zaspokoić indywidualnych potrzeb finansowych i prowadzą do nieprzestrzegania, przez uczestników programu emerytalnego, zasady zrównoważenia swoich portfeli;

- zbytnia pewność siebie - w literaturze z zakresu psychologii wskazuje się na istnienie co najmniej dwóch czynników, które mogą przyczynić się do nadmiernej pewności siebie, są to: iluzja wiedzy i złudzenie kontroli. Iluzja wiedzy występuje wówczas, gdy mamy do czynienia z dużą ilością informacji, i automatycznie przyjmujemy, że informacje zostały poprawnie zinterpretowane oraz mogą zostać użyte mądrze. Wielu inwestorów nie ma umiejętności lub przeszkolenia $\mathrm{w}$ zakresie pełnego interpretowania informacji. Iluzja kontroli odnosi się natomiast do przekonania, że mamy kontrolę, podczas gdy zdarzenia mają charakter niekontrolowany ${ }^{3}$;

- brak zrozumienia i wiedzy u konsumenta - wyniki badań prowadzone na rynku amerykańskim i brytyjskim świadczą o tym, że podmiotom indywidualnym brak wiedzy i zrozumienia do podejmowania emerytalnych decyzji inwestycyjnych. Clark i Strauss (2008) przytaczają dowody z USA, które stawiają pod znakiem zapytania zdolność uczestników programu świadczeń emerytalnych, do podejmowania decyzji, które są zgodne z ich długoterminowymi potrzebami finansowymi, ze względu na brak wiedzy finansowej i zrozumienia problematyki emerytalnej ${ }^{4}$.

\footnotetext{
${ }^{3}$ W. Tapia, J. Yermo, op. cit., s. 4-9.

${ }^{4}$ S. Collard, op. cit., s. 8.
} 


\section{INDYWIDUALNE KONTA EMERYTALNE (IKE) I INDYWIDUALNE KONTA ZABEZPIECZENIA EMERYTALNEGO (IKZE) - ROZWIĄZANIA PRAWNE}

System zabezpieczania emerytalnego w Polsce opiera się na trzech filarach. Pierwszy filar, obowiązkowy, to zreformowany system repartycyjny, administrowany przez Zakład Ubezpieczeń Społecznych. W filarze tym uczestnicy planu nie mają możliwości podejmowania decyzji zarówno w fazie gromadzenia kapitału, ani też $\mathrm{w}$ fazie konsumowania kapitału. W przypadku Polski można jednak łączyć dochody z pracy ze świadczeniem emerytalnym wypłacanym z pierwszego filaru. Drugi filar, również obowiązkowy, posiada charakter kapitałowy, tworzą go otwarte fundusze emerytalne oraz zarządzające nimi powszechne towarzystwa emerytalne. W tym filarze uczestnik planu emerytalnego ma możliwość dokonania wyboru otwartego funduszu emerytalnego (według stanu prawnego na 15 listopada 2013 r.). Trzeci filar, dobrowolny, to pracownicze programy emerytalne oferowane przez pracodawców w zakładach pracy, indywidualne konta emerytalne oraz indywidualne konta zabezpieczenia emerytalnego. Trzeci filar stwarza szerokie możliwości wyboru spośród różnych form zabezpieczenia emerytalnego. Osoby indywidualne stają tu przed decyzjami dotyczącymi zakresu uczestnictwa w dobrowolnym systemie emerytalnym, wyboru instytucji finansowej oferującej produkty emerytalne, formy oszczędzania, wartości gromadzonych środków, długości okresu oszczędzania, czy też formy konsumpcji zgromadzonych oszczędności emerytalnych ${ }^{5}$.

W dalszej części rozpatrywane będą kwestie dotyczące wyboru zabezpieczenia emerytalnego $\mathrm{w}$ ramach indywidualnych kont emerytalnych i indywidualnych kont zabezpieczenia emerytalnego.

Prawo do wpłat na IKE lub IKZE przysługuje osobie fizycznej, która ukończyła 16 lat. Małoletni mają prawo do dokonywania wpłat na IKE lub IKZE tylko w roku kalendarzowym, w którym uzyskują dochody z pracy wykonywanej na podstawie umowy o pracę (art. 3). Na IKE lub IKZE może gromadzić oszczędności wyłącznie jeden oszczędzający (art. 5).

IKE lub IKZE jest prowadzone na podstawie pisemnej umowy zawartej przez oszczędzającego:

- z funduszem inwestycyjnym,

- $\mathrm{z}$ dobrowolnym funduszem emerytalnym,

- z podmiotem prowadzącym działalność maklerską o świadczenie usług polegających na wykonywaniu zleceń nabycia lub zbycia instrumentów finansowych i prowadzenie rachunku papierów wartościowych oraz rachunku pieniężnego,

- z zakładem ubezpieczeń - ubezpieczenia na życie z ubezpieczeniowym funduszem kapitałowym,

- $\mathrm{z}$ bankiem o prowadzenie rachunku bankowego (art. 8).

${ }^{5} \mathrm{~F}$. Ch y bals ki, Problem racjonalności $w$ decyzjach emerytalnych. Rozważania teoretyczne. „Prace Naukowe Uniwersytetu Ekonomicznego w Wrocławiu” 2002, nr 262, Wrocław, s. 64-75. 
Wpłaty dokonywane na IKE w roku kalendarzowym nie mogą przekroczyć kwoty odpowiadającej trzykrotności przeciętnego prognozowanego wynagrodzenia miesięcznego w gospodarce narodowej na dany rok, określonego w ustawie budżetowej lub ustawie o prowizorium budżetowym lub w ich projektach, jeżeli odpowiednie ustawy nie zostały uchwalone (art. 13). Natomiast wpłaty dokonywane na IKZE w roku kalendarzowym nie moga przekroczyć kwoty odpowiadającej równowartości $4 \%$ podstawy wymiaru składki na ubezpieczenie emerytalne, ustalonej dla oszczędzającego za rok poprzedni, nie więcej jednak niż 4\% kwoty ograniczenia rocznej podstawy wymiaru składek na ubezpieczenia emerytalne i rentowe ogłoszonej na podstawie art. 19 ust. 10 Ustawy $z$ dnia 13 października 1998 r. o systemie ubezpieczeń społecznych (DzU 2009, $\mathrm{nr}$ 205, poz. 1585 , z późn. zm.) na rok poprzedni (art. 13a). Pomimo, iż IKZE w dużej mierze oparte są na rozwiązaniach przyjętych w funkcjonujących wcześniej IKE, to należy zwrócić uwagę na zasadniczą różnicę jaka ma miejsce w regulacjach dotyczących opodatkowania. W IKZE zastosowano preferencję podatkową polegającą na odliczaniu od podstawy opodatkowania podatkiem dochodowym od osób fizycznych wpłat na to konto. Natomiast opodatkowaniu PIT będzie podlegała wypłata z IKZE po zakończeniu okresu oszczędzania, zwrot środków zgromadzonych na tym koncie oraz wypłata środków zgromadzonych przez oszczędzającego na IKZE na rzecz osoby uprawnionej na wypadek śmierci oszczędzającego. Jest to inne rozwiązanie niż przyjęte przy IKE, gdzie na to konto wpłacane są środki już po opodatkowaniu, a wypłata zarówno dla oszczędzających, jak i uprawnionych jest zwolniona z podatku dochodowego ${ }^{6}$.

Wypłata środków zgromadzonych na IKE następuje wyłącznie:

1) na wniosek oszczędzającego po osiaggnięciu przez niego wieku 60 lat lub nabyciu uprawnień emerytalnych i ukończeniu 55 roku życia oraz spełnieniu warunku:

a) dokonywania wpłat na IKE, co najmniej w 5 dowolnych latach kalendarzowych, albo

b) dokonania ponad połowy wartości wpłat nie później niż na 5 lat przed dniem złożenia przez oszczędzającego wniosku o dokonanie wypłaty;

2) w przypadku śmierci oszczędzającego - na wniosek osoby uprawnionej.

Wypłata może być, w zależności od wniosku oszczędzającego, albo osoby uprawnionej, dokonywana jednorazowo, albo w ratach (art. 34).

Wypłata środków zgromadzonych na IKZE następuje wyłącznie:

1) na wniosek oszczędzającego, po osiągnięciu przez niego wieku 65 lat oraz pod warunkiem dokonywania wpłat na IKZE, co najmniej w 5 latach kalendarzowych;

2) w przypadku śmierci oszczędzającego - na wniosek osoby uprawnionej.

${ }^{6}$ Ministerstwo Pracy i Polityki Społecznej, Indywidualne konta zabezpieczenia emerytalnego, http://www.mpips.gov.pl/ubezpieczenia-spoleczne/ubezpieczenie-emerytalne/ikze/. 
Wypłata może być, w zależności od wniosku oszczędzającego, albo osoby uprawnionej, dokonywana jednorazowo, albo w ratach (art. 34a).

Wypłata transferowa jest dokonywana:

1) $\mathrm{z}$ instytucji finansowej prowadzącej IKE lub IKZE do innej instytucji finansowej, z którą oszczędzający zawarł umowę o prowadzenie IKE lub IKZE, albo

2) $\mathrm{z}$ instytucji finansowej prowadzącej IKE do programu emerytalnego, do którego przystąpił oszczędzający, albo

3) z programu emerytalnego, w przypadkach, o których mowa w przepisach o pracowniczych programach emerytalnych, do instytucji finansowej, z którą oszczędzający zawarł umowę o prowadzenie IKE, albo

4) z IKE zmarłego oszczędzającego na IKE osoby uprawnionej, albo do programu emerytalnego, do którego uprawniony przystapił, albo

5) z IKZE zmarłego oszczędzającego na IKZE osoby uprawnionej (art. 35).

Zwrot środków zgromadzonych na IKE lub IKZE następuje w razie wypowiedzenia umowy o prowadzenie IKE lub IKZE przez którąkolwiek ze stron, jeżeli nie zachodzą przesłanki do wypłaty lub wypłaty transferowej (art. 37).

Wypłata, wypłata transferowa, częściowy zwrot oraz zwrot środków zgromadzonych na IKE lub IKZE są dokonywane w formie pieniężnej (art. 38) ${ }^{7}$.

\section{INDYWIDUALNE KONTA EMERYTALNE (IKE) I INDYWIDUALNE KONTA ZABEZPIECZENIA EMERYTALNEGO (IKZE) - PODSTAWOWE DANE}

Oszczędzanie w systemie IKE, IKZE charakteryzuje się dużą elastycznością zarówno w zakresie formy oszczędzania (umowa ubezpieczenia na życie zawarta z zakładem ubezpieczeń, lokaty w banku, rachunek maklerski itp.), jak i wyboru konkretnej instytucji finansowej, w której prowadzone jest IKE, czy IKZE.

W 2012 r. IKE posiadało 813,3 tys. osób, co stanowiło 5,2\% liczby osób aktywnych zawodowo - produkt emerytalny na rynku od 2004. W 2012 r. IKZE posiadało 496,8 tys. osób, co stanowiło 3,2\% liczby osób aktywnych zawodowo - produkt emerytalny na rynku polskim od 2012. Wartości 5,2\% i 3,2\% wydają się być wyjątkowo niskie w kontekście niekorzystnych zmian demograficznych zachodzących w Polsce ${ }^{8}$.

Wartość wskaźnika DR (ang. old-age dependency ratio, DR) w Polsce jeszcze w 1980 r. kształtowała się na poziomie 19,9\% - co oznacza, iż na jedną

${ }^{7}$ Ustawa z dnia 20 kwietnia 2004 r. o indywidualnych kontach emerytalnych oraz indywidualnych kontach zabezpieczenia emerytalnego, DzU 2004, nr 116, poz. 1205; DzU 2005, nr 183, poz. 1538; DzU 2006, nr 157, poz. 1119; DzU 2008, nr 220, poz. 1432; DzU 2009, nr 165, poz. 1316; DzU 2010, nr 18, poz. 98; nr 257, poz. 1724; DzU 2011, nr 75, poz. 398; nr 171, poz. 1016.

${ }^{8}$ Indywidualne konta emerytalne oraz indywidualne konta zabezpieczenia emerytalnego w 2012 roku, Urząd Komisji Nadzoru Finansowego, Warszawa 2013, s. 3-4. 
osobę w wieku emerytalnym przypadało pięć osób w wieku produkcyjnym. Po roku 2015 na jednego emeryta zaczną przypadać już tylko 3 osoby w wieku produkcyjnym, a przed rokiem 2025 relacja ta osiagnie wartość $2: 5^{9}$.

Dlaczego więc tak niewiele osób czynnych zawodowo zdecydowało się na oszczędzanie w ramach trzeciego filaru zabezpieczenia emerytalnego?

Po pierwsze - zbyt wiele opcji wyboru powoduje przeciążenie informacją. Może to prowadzić do spadku liczby ubezpieczonych w ramach dobrowolnego systemu zabezpieczenie emerytalnego.

W końcu roku 2012 IKE były prowadzone przez 52 instytucje finansowe:

- 12 zakładów ubezpieczeń na życie,

- fundusze inwestycyjne zarządzane przez 15 towarzystw funduszy inwestycyjnych,

- 7 podmiotów prowadzących działalność maklerską,

- 13 banków,

- dobrowolne fundusze emerytalne zarządzane przez 4 powszechne towarzystwa emerytalne ${ }^{10}$.

W końcu 2012 r. IKZE były prowadzone przez 33 instytucje finansowe:

- 7 zakładów ubezpieczeń na życie,

- fundusze inwestycyjne zarządzane przez 12 towarzystw funduszy inwestycyjnych,

- 4 podmioty prowadzące działalność maklerską,

- 1 bank,

- dobrowolne fundusze emerytalne zarządzane przez 9 powszechnych towarzystw emerytalnych ${ }^{11}$.

Wielość instytucji oferujących IKE i IKZE powoduje, że mamy do czynienia $\mathrm{z}$ różnicami $\mathrm{w}$ :

- strukturze governance - struktura governance powinna zapewniać właściwy podział obowiązków operacyjnych i nadzorczych oraz określać zakres odpowiedzialności i predyspozycje tych, którym powierzono w funduszu emerytalnym określone obowiązki. Obejmuje ona: identyfikację zakresu obowiązków, organ zarządzający, fachowe doradztwo, audytora, aktuariusza, depozytariusza, odpowiedzialność, predyspozycje;

- mechanizmach governance - wypracowane odpowiednie mechanizmy kontrolne, komunikacji oraz bodźców zachęcające do podejmowania dobrych decyzji, właściwej i terminowej ich realizacji oraz regularnych analiz i ocen. $\mathrm{Na}$

${ }^{9}$ M. Popek, M. Szymański, Pomyśl o swojej emeryturze. Już dziś. Poradnik klienta ustug finansowych, KNF, Warszawa 2012, s. 7.

${ }^{10}$ Indywidualne konta..., op. cit., s. 8.

${ }^{11}$ Ibidem, s. 20. 
mechanizmy governance składają się: kontrole wewnętrzne, raportowanie, ujawnianie informacji, dochodzenie roszczeń ${ }^{12}$;

- efektywności administracyjnej - operacyjne koszty zarządzania funduszem emerytalnym mogą mieć bardzo znaczący wpływ na wysokość przyszłych świadczeń emerytalnych. Najważniejszym czynnikiem decydującym o efektywności administracyjnej w funduszu emerytalnym jest jego struktura governance oraz przyjęte rozwiązania prawne;

- strategii inwestycyjnej - zarówno struktura governance, jak i regulacje zewnętrzne odgrywają kluczową rolę w kształtowaniu strategii inwestycyjnej. Pierwsza określa cele inwestycyjne, strategie i narzędzia stosowane przez zarządzających funduszami, a druga może mieć wpływ na alokację aktywów portfela $^{13}$.

Wielość instytucji oferujących IKE i IKZE powoduje, iż rośnie złożoność decyzji emerytalnych, co sprawia, że jednostki odkładają je w czasie. Narasta zjawisko opieszałości w decyzjach inwestycyjnych. Ponadto im więcej opcji wyboru, tym trudniej podjąć decyzję inwestycyjną. Potrzeba na nią więcej czasu, rosną koszty pozyskania informacji, rośnie też wysiłek umysłowy, co prowadzi do narastania zjawiska inercji, polegającego na utrzymaniu porządku rzeczy takim, jakim on jest. W efekcie duża część podmiotów indywidualnych rezygnuje $z$ oszczędzania w ramach trzeciego filaru zabezpieczenia emerytalnego.

Po drugie, zwrócić należy uwagę na brak wiedzy i zrozumienia problematyki emerytalnej w społeczeństwie, co po części potwierdzają wyniki badań Centrum Badań Opinii Społecznej (CBOS). W maju 2010 r. CBOS wraz z Izbą Zarządzających Funduszami i Aktywami przeprowadził badanie dotyczycące opinii Polaków na temat dodatkowego oszczędzania na emeryturę ${ }^{14}$. Ponad jedna trzecia Polaków w wieku produkcyjnym ${ }^{15}$ (36\%) nie była w stanie oszacować wysokości swojej przyszłej emerytury. Oznacza to, że znacząca część społeczeństwa polskiego nie wie, na jakim poziomie będzie żyć po zakończeniu kariery zawodowej, oraz jaką kwotą będzie dysponować każdego miesiąca. $Z$ jednej strony świadczy to o tym, iż część społeczeństwa nie myśli o swojej przyszłości, $\mathrm{z}$ drugiej o braku opinii w tej kwestii, co związane może być z trudnością w prognozowaniu swojej sytuacji dochodowej w długim okresie.

${ }^{12}$ A. S a mborski, Pension Funds Governance, [w:] M. S zczepańs ki (red.), Old-Age Crisis and Pension Reform. Where do we stand?, Publishing House of Poznan University of Technology, Poznań 2013, s. 131-132.

${ }_{13}$ A. S a mb or ski, Governance $w$ funduszach emerytalnych, strategie inwestycyjne i ich rola $w$ nadzorze korporacyjnym. Przykład otwartych funduszy emerytalnych, [w:] M. S z c z e p ań s ki (red.). Reformowanie systemów emerytalnych - porównania i oceny, Wydawnictwo Politechniki Poznańskiej, Poznań 2013, s. 219-220.

${ }^{14}$ Polacy o dodatkowym oszczędzaniu na emeryturę. Komunikat z badań, Centrum Badań Opinii Społecznej, Izba Zarządzających Funduszami i Aktywami, BS/77/2010, CBOS, Warszawa 2010.

${ }^{15}$ Kobiety do 59 roku życia włącznie i mężczyźni do roku 64 życia włącznie. 
Wyniki badań CBOS świadczą również o niskiej skłonności Polaków do dodatkowego oszczędzania na emeryturę. Jedynie $13 \%$ osób w wieku produkcyjnym deklaruje, że oszczędza z myślą o emeryturze, a kolejne $21 \%$ deklaruje, że obecnie nie oszczędza, ale zamierza to robić. Ponad połowa respondentów będących w wieku produkcyjnym (55\%) twierdzi, że nie oszczędza z myślą o wieku emerytalnym i nie zamierza tego robić.

Skłonność do oszczędzania na przyszłą emeryturę wykazuje związek z wykształceniem badanych, ich dochodami i wiekiem. Im wykształcenie respondentów jest wyższe, tym więcej oszczędzających. Wraz z niższymi dochodami spada liczba oszczędzających. Im wiek badanych jest niższy, tym mniejszy odsetek oszczędzających.

Wszystkich respondentów zapytano również o opinie na temat najlepszego sposobu oszczędzania na emeryturę. Znacząca grupa (29\%) nie potrafiła jednak wskazać, który ze sposobów oszczędzania jest najlepszy. Pozostali badani, najczęściej jako najlepszy dodatkowy sposób oszczędzania na emeryturę, wskazywali zakup nieruchomości, działek, czy też gruntów rolnych. Jeżeli chodzi o produkty finansowe na pierwszym miejscu, pod względem częstości wskazań znalazła się lokata bankowa. Warto w tym miejscu podkreślić, iż zainteresowanie produktami emerytalnymi wśród badanych Polaków w wieku produkcyjnym było marginalne ${ }^{16}$.

Po trzecie, przyczyn niskiego zainteresowania IKE i IKZE upatrywać należy w niskiej efektywności stanowienia prawa, zmienności polityki gospodarczej, czy negatywnych doświadczeniach z przeszłości.

Proces tworzenia prawa w Polsce jest niedostosowany do wyzwań rozwojowych zarówno o charakterze wewnętrznym, jak i zewnętrznym. Proces tworzenia prawa w Polsce nie sprzyja również budowaniu zasługującej na zaufanie sprawnej władzy publicznej. Do wad prawotwórstwa zaliczyć należy brak skuteczności przyjmowanych rozwiązań prawnych, co przejawia się w częstym nowelizowaniu uchwalanych ustaw, zbyt dużej liczbie regulacji prawnych, niestabilności i niespójności unormowań prawych, czy też braku przejrzystości systemu prawnego, oraz niskim poziomie techniczno-legislacyjnym. W efekcie prawo zamiast służyć dobru wspólnemu i kształtować więzi między ludźmi, staje się źródłem napięć, podziałów i konfliktów ${ }^{17}$.

Trzeba w tym miejscu wskazać również na zmienność polityki gospodarczej. Polityka gospodarcza coraz częściej jest traktowana jako wyraz woli konkretnej większości parlamentarnej. Brak jest konsekwencji w działaniu, w dłuższej niż kadencja parlamentu perspektywie czasu.

${ }^{16}$ Ibidem, s. 3-11.

17 R. Pi otrowski, Efektywność stanowienia prawa, systemu wymiaru sprawiedliwości i praw konsumenta warunkiem sprawnego państwa, Pomoc Techniczna. Narodowa Strategia Spójności. Projekt współfinansowany ze środków Europejskiego Funduszu Rozwoju Regionalnego, www.google.com. 
Nie sposób nie wspomnieć również o negatywnych doświadczeniach z przeszłości. Wysokiej inflacji początku lat 90., czy też utracie prywatnej własności oraz oszczędności w konsekwencji nacjonalizacji okresu socjalizmu oraz pierwszej i drugiej wojny światowej.

Otoczenie prawne, gospodarcze i doświadczenia z przeszłości nie zachęcają więc do inwestycji o charakterze długoterminowym.

Analizując dane statystyczne dotyczące trzeciego filaru zabezpieczenia emerytalnego, warto też zwrócić uwagę na zróżnicowanie podmiotów względem płci i wieku wśród posiadaczy IKE i IKZE.

Z badań empirycznych wynika, iż kobiety cechuje większa, niż u mężczyzn, awersja do ryzyka, w szczególności w obszarze finansów ${ }^{18}$.

Na koniec 2012 r. funkcjonowało 813,2 tys. IKE, z czego 428,5 tys. $(52,7 \%)$ umów zostało zawartych przez kobiety, a 384,7 tys. $(47,3 \%)$ przez mężczyzn. W tym samym czasie funkcjonowało 496,8 tys. IKZE, z czego 252,1 tys. $(50,7 \%)$ umów zostało zawartych przez kobiety, a 244,7 tys. (49,3\%) przez mężczyzn ${ }^{19}$.

Warto zastanowić się nad tym, dlaczego kobiety stanowią większość oszczędzających w IKE i IKZE? Kobiet pracujących w gospodarce polskiej jest przecież mniej niż mężczyzn i otrzymują też niższe wynagrodzenie. Trzeba jednak zwrócić uwagę na fakt, iż oczekiwana dalsza długość trwania życia w grupie kobiet przyjmuje większą wartość (81,1 lat - dla kobiet urodzonych w 2011 r.) niż w grupie mężczyzn (72,6 lat - dla mężczyzn urodzonych w 2011 r. $)^{20}$. W efekcie większa liczba kobiet niż mężczyzn oszczędza w trzecim filarze.

W 2012 r. wśród oszczędzających na IKE najbardziej liczną grupą były osoby w wieku 51-60 lat, które posiadały 238,9 tys. IKE (29,4\% ogółu kont). Najmniejszy odsetek kont posiadały osoby najmłodsze oszczędzające na IKE (do 30 lat $-6,5 \%$ ). Największy udział w liczbie funkcjonujących IKZE, ze względu na wiek, miały osoby w wieku $31-50$ lat (54,3\%). W pierwszym roku funkcjonowania IKZE częściej tę formę dobrowolnego oszczędzania na emeryturę wybierały osoby w średnim wieku oraz młode (do 30 lat $-19,9 \%)^{21}$.

Różnice te wynikają przede wszystkim z różnicy w konstrukcji, a dokładniej z limitu wpłat. W przypadku IKE limit w 2012 r. wynosił 10578 PLN, w przypadku natomiast IKZE limit w 2012 r. wyniósł 4030 PLN. W przypadku osób starszych, które wcześniej przejdą na emeryturę korzystniejsze okazało się IKE, które pozwala inwestować większe kwoty. Posiadacz IKE wpłacił w 2012 r. na swoje konto średnio kwotę 2584 zł. W przypadku osób młodszych inwestu-

${ }^{18}$ S. Coll ard, op. cit., s. 4.

${ }^{19}$ Indywidualne konta..., op. cit., s. 8-9, 20.

${ }^{20}$ Eurostat, Life expectancy at birth, by sex, http://epp.eurostat.ec.europa.eu/tgm/refresh TableAction.do;jsessionid=9ea7d07e30e82b9fca59ea3544c9a189d0bc6a2c79cc.e34OaN8Pc3mM c40Lc3aMaNyTb38Ne0?tab=table\&plugin $=1 \&$ pcode $=$ tps00025\&language $=$ en.

${ }^{21}$ Indywidualne konta..., op. cit., s. 8-9, 20. 
jących mniejsze kwoty bardziej korzystne okazało się natomiast IKZE. Oszczędzający na IKZE wpłacił w 2012 r. przeciętnie kwotę 798 zł $^{22}$.

\section{INDYWIDUALNE ZACHOWANIA INWESTYCYJNE NA RYNKU PRODUKTÓW EMERYTALNYCH. PRZYKŁAD IKE PZU}

Indywidualne Konta Emerytalne PZU, zarówno w wariancie oferowanym przez PZU Życie SA, jak i TFI PZU SA, stanowią dwa programy inwestowania, określane mianem: rekomendowany i indywidualny. W każdym z nich obowiązują ściśle określone zasady podziału wpłacanych składek pomiędzy fundusze należące do różnych kategorii ${ }^{23}$.

Program rekomendowany przeznaczony jest dla osób, które: ceniq wygodę, wysokie zyski $i$ bezpieczeństwo powierzonych środków ${ }^{24}$. W programie tym podział inwestycyjnej części składki na poszczególne fundusze uzależniony jest od wieku oszczędzającego i realizowany jest zgodnie z tab. 1.

Tabela 1

Podział inwestycyjnej części składki na poszczególne fundusze w programie rekomendowanym

\begin{tabular}{|l|c|c|c|}
\hline $\begin{array}{c}\text { Wiek } \\
\text { oszczędzającego }\end{array}$ & Fundusz Akcji & $\begin{array}{c}\text { Fundusz Stabilnego } \\
\text { Wzrostu }\end{array}$ & $\begin{array}{c}\text { Fundusz } \\
\text { Papierów Dłużnych }\end{array}$ \\
\hline \hline Do 25 lat & $50,0 \%$ & $50,0 \%$ & $0 \%$ \\
\hline Od 26 lat do 30 lat & $40,0 \%$ & $60,0 \%$ & $0 \%$ \\
\hline Od 31 lat do 35 lat & $30,0 \%$ & $70,0 \%$ & $0 \%$ \\
\hline Od 36 lat do 40 lat & $20,0 \%$ & $80,0 \%$ & $0 \%$ \\
\hline Od 41 lat do 45 lat & $10,0 \%$ & $90,0 \%$ & $0 \%$ \\
\hline Od 46 lat do 50 lat & $0,0 \%$ & $100,0 \%$ & $0 \%$ \\
\hline Od 51 lat do 55 lat & $0,0 \%$ & $87,5 \%$ & $12,5 \%$ \\
\hline Od 56 lat & $0,0 \%$ & $75,0 \%$ & $25,0 \%$ \\
\hline
\end{tabular}

Źródło: ogólne warunki indywidualnego ubezpieczenia na życie związanego z ubezpieczeniowym funduszem kapitałowym IKE PZU Życie, http://www.pzu.pl/c/document_library/get_file? uuid=78fa3765-46ef-415a-a630-d36a4747924a\&groupId=10172.

Oszczędzający, który wskazał indywidualny program inwestowania, dokonuje wyboru funduszy, do których będą wnoszone inwestycyjne części składki.

${ }^{22}$ Ibidem, s. 12, 22.

${ }^{23}$ IKE - Indywidualne Konto Emerytalne PZU, http://akcje.bankier.pl/gfx/centrum/pzu/emerytura_ike.html.

${ }^{24}$ Indywidualne Konto Emerytalne IKE PZU, http://www.pzu.pl/produkty/indywidualnekonto-emerytalne-ike-pzu. 
Fundusze możliwe do wyboru w ramach rachunku IKE to: Fundusz Akcji, Fundusz Stabilnego Wzrostu, Fundusz Papierów Dłużnych, Fundusz Gotówkowy, Fundusz Akcji Nowa Europa, Fundusz Zrównoważony. Oszczędzający dokonuje wyboru, co najmniej jednego funduszu. W programie indywidualnym wpłaty dzielone są pomiędzy fundusze inwestycyjne, zgodnie z życzeniem oszczędzającego. Oszczędzający może wpłacać całość do jednego, wybranego funduszu inwestycyjnego lub dzielić wpłaty $\mathrm{w}$ dowolnych procentowych proporcjach pomiędzy poszczególne fundusze. Wybrany podział środków w każdej chwili może być zmieniony, zgodnie z dyspozycją oszczędzającego ${ }^{25}$.

Oszczędzający musi więc zdecydować czy wybrać program rekomendowany, czy też wskazać indywidualny program inwestowania. W przypadku wyboru programu indywidualnego oszczędzający musi zdecydować w ile funduszy zainwestować, jakie powinny to być fundusze oraz jak ukształtować strukturę inwestycji. W takich sytuacjach decyzyjnych Benartzi i Thaler (2001) znaleźli dowody na istnienie strategii $1 / \mathrm{n}$ (strategii naiwnej dywersyfikacji), zgodnie, z którą oszczędzający dzieli składkę równo między $n$ funduszy oferowanych przez plan emerytalny ${ }^{26}$.

Tabela 2

Rodzaj funduszu i struktura aktywów IKE PZU (stan na dzień 30.06.2013 r.)

\begin{tabular}{|c|c|c|c|c|c|}
\hline \multirow[b]{2}{*}{ Nazwa funduszu } & \multirow{2}{*}{$\begin{array}{l}\text { Udział w aktywach } \\
\text { IKE PZU ogółem }\end{array}$} & \multicolumn{4}{|c|}{ Struktura aktywów } \\
\hline & & akcje & $\begin{array}{l}\text { dłużne skar- } \\
\text { bowe }\end{array}$ & $\begin{array}{l}\text { dłużne nie } \\
\text { skarbowe }\end{array}$ & inne \\
\hline Fundusz Akcji & $12,3 \%$ & $95,8 \%$ & $0 \%$ & $0 \%$ & $4,2 \%$ \\
\hline $\begin{array}{l}\text { Fundusz Stabilnego } \\
\text { Wzrostu }\end{array}$ & $54,0 \%$ & $32,9 \%$ & $56,7 \%$ & $5,0 \%$ & $5,5 \%$ \\
\hline $\begin{array}{l}\text { Fundusz Papierów } \\
\text { Dłużnych }\end{array}$ & $14,4 \%$ & $0,0 \%$ & $84,0 \%$ & $9,2 \%$ & $6,8 \%$ \\
\hline $\begin{array}{l}\text { Fundusz } \\
\text { Gotówkowy }\end{array}$ & $15,5 \%$ & $0,0 \%$ & $96,5 \%$ & $1,2 \%$ & $2,3 \%$ \\
\hline $\begin{array}{l}\text { Fundusz Akcji } \\
\text { Nowa Europa }\end{array}$ & $0,6 \%$ & $93,6 \%$ & $0,0 \%$ & $0,0 \%$ & $6,4 \%$ \\
\hline $\begin{array}{l}\text { Fundusz } \\
\text { Zrównoważony }\end{array}$ & $3,2 \%$ & $62,1 \%$ & $31,3 \%$ & $2,3 \%$ & $4,3 \%$ \\
\hline
\end{tabular}

Żródło: www.analizy.pl.

Dane udostępnione przez PZU i gromadzone w serwisie informacyjnym www.analizy.pl mają jednak charakter zbiorczy i nie pozwalają na dokonanie

${ }^{25}$ Ogólne warunki indywidualnego ubezpieczenia na życie zwiazanego z ubezpieczeniowym funduszem kapitatowym IKE PZU Życie, http://www.pzu.pl/c/document_library/get_file?uuid= 78fa3765-46ef-415a-a630-d36a4747924a\&groupId=10172.

${ }^{26}$ W. Tapia, J. Yermo,op. cit., s. 7. 
oddzielnych analiz programu indywidualnego. $\mathrm{Z}$ analizy struktury aktywów IKE PZU wynika, iż część inwestycyjną składek oszczędzający ulokowali przede wszystkim w Funduszu Stabilnego Wzrostu, a w strukturze aktywów dominują dłużne papiery skarbowe (zob. tab. 2).

Warto w tym miejscu zastanowić się nad przyczynami takiej alokacji aktywów w IKE PZU.

Po pierwsze, zbyt wiele opcji inwestycyjnych może wywołać efekt przeciążenia informacją, skutkujący wyborem opcji domyślnej - w przypadku IKE PZU jest to program rekomendowany.

Po drugie, efekt przeciążenia informacją wpływa również na alokację aktywów, powodując u oszczędzających redukcję ekspozycji na akcje.

Po trzecie, wspomnieć trzeba o „efekcie ramki” polegającym na tym, że oszczędzający wybiera opcję eksponowaną w materiałach informacyjnych ${ }^{27}$. Tak jest w przypadku programu rekomendowanego, przeznaczonego dla tych, którzy: ceniq wygodę, wysokie zyski i bezpieczeństwo powierzonych środków ${ }^{28}$. W programie rekomendowanym Fundusz Stabilnego Wzrostu odgrywa podstawową rolę we wszystkich grupach wiekowych (zob. tab. 1).

W efekcie wybór aktywny inwestycji u oszczędzających w IKE PZU ma marginalne znaczenie.

\section{PODSUMOWANIE}

Zainteresowanie w Polsce dobrowolnymi formami zabezpieczenia emerytalnego jest marginalne. Aby pobudzić rozwój tej formy oszczędzania należy:

- stworzyć prostsze ramy dla produktów emerytalnych - np. poprzez ograniczenie ilości podmiotów mogących oferować IKE i IKZE,

- prowadzić akcje edukacyjne ukierunkowane na zrozumienie istoty wyborów finansowych - tj. poprawić podstawową znajomość zagadnień finansowych, tak aby jednostki stały się lepiej przygotowane do samodzielnych decyzji finansowych,

- lepiej chronić członków planów emerytalnych - poprzez lepszą ochronę praw konsumentów, zapewniającą poczucie bezpieczeństwa tym, którzy zdecydują się na przystąpienie do planu emerytalnego,

- upowszechniać dobre praktyki wśród podmiotów oferujących produkty emerytalne ${ }^{29}$.

${ }^{27}$ W. T a pia, J. Yermo, op. cit.

${ }^{28}$ Indywidualne Konto Emerytalne IKE PZU, op. cit.

${ }^{29}$ Simplicity, security and choice: Working and saving for retirement - a summary, Department for Work and Pensions, DWP UK 2002. 


\section{BIBLIOGRAFIA}

Chybalski F., Problem racjonalności $w$ decyzjach emerytalnych. Rozważania teoretyczne, „Prace Naukowe Uniwersytetu Ekonomicznego w Wrocławiu” 2002, nr 262, Wrocław.

Collard S., Individual investment behaviour: A brief review of research, Personal Finance Research Centre. Final report, University of Bristol, Bristol 2009.

Eurostat, Life expectancy at birth, by sex, http://epp.eurostat.ec.europa.eu/tgm/refreshTableAction.do;jsessionid=9ea7d07e30e82b9fca59ea3544c9a189d0bc6a2c79cc.e34OaN8Pc3mMc40 Lc3aMaNyTb38Ne0?tab=table \&plugin $=1 \&$ pcode $=$ tps00025\&language $=e n$.

IKE - Indywidualne Konto Emerytalne PZU, http://akcje.bankier.pl/gfx/centrum/pzu/emerytura ike.html.

Indywidualne konta emerytalne oraz indywidualne konta zabezpieczenia emerytalnego w 2012 roku, Urząd Komisji Nadzoru Finansowego, Warszawa 2013.

Indywidualne Konto Emerytalne IKE PZU, http://www.pzu.pl/produkty/indywidualne-kontoemerytalne-ike-pzu.

Ministerstwo Pracy i Polityki Społecznej, Indywidualne konta zabezpieczenia emerytalnego, http://www.mpips.gov.pl/ubezpieczenia-spoleczne/ubezpieczenie-emerytalne/ikze/.

Ogólne warunki indywidualnego ubezpieczenia na życie zwiqzanego z ubezpieczeniowym funduszem kapitałowym IKE PZU Życie, http://www.pzu.pl/c/document_library/get_file?uuid $=78 \mathrm{fa} 3765-46 \mathrm{ef}-415 \mathrm{a}-\mathrm{a} 630-\mathrm{d} 36 \mathrm{a} 4747924 \mathrm{a} \&$ groupId=10172.

Piotrowski R., Efektywność stanowienia prawa, systemu wymiaru sprawiedliwości i praw konsumenta warunkiem sprawnego państwa, Pomoc Techniczna. Narodowa Strategia Spójności. Projekt współfinansowany ze środków Europejskiego Funduszu Rozwoju Regionalnego, www.google.com.

Polacy o dodatkowym oszczędzaniu na emeryture Komunikat z badań, Centrum Badań Opinii Społecznej, Izba Zarządzających Funduszami i Aktywami, BS/77/2010, CBOS, Warszawa 2010.

Popek M., Szymański M., Pomyśl o swojej emeryturze. Już dziś. Poradnik klienta ustug finansowych, KNF, Warszawa 2012.

Samborski A., Governance $w$ funduszach emerytalnych, strategie inwestycyjne $i$ ich rola w nadzorze korporacyjnym. Przyktad otwartych funduszy emerytalnych, [w:] M. S zczep ańs ki (red.), Reformowanie systemów emerytalnych - porównania i oceny, Wydawnictwo Politechniki Poznańskiej, Poznań 2013.

S a mbor s k i A., Pension Funds Governance, [w:] M. S z c ze pań s ki (red.), Old-Age Crisis and Pension Reform. Where do we stand?, Publishing House of Poznan University of Technology, Poznań 2013.

Simplicity, security and choice: Working and saving for retirement - a summary, Department for Work and Pensions, DWP UK 2002.

T a p i a W, Y e r mo J., Implications of Behavioural Economics for Mandatory Individual Account Pension Systems, OECD Working Papers on Insurance and Private Pensions, No. 11, OECD Publishing, Paris 2007.

Ustawa z dnia 20 kwietnia 2004 r. o indywidualnych kontach emerytalnych oraz indywidualnych kontach zabezpieczenia emerytalnego, DzU 2004, nr 116, poz. 1205; DzU 2005, nr 183, poz. 1538; DzU 2006, nr 157, poz. 1119; DzU 2008, nr 220, poz. 1432; DzU 2009, nr 165, poz. 1316; DzU 2010, nr 18, poz. 98; nr 257, poz. 1724; DzU 2011, nr 75, poz. 398; nr 171, poz. 1016. 


\section{Adam Samborski}

\section{COMPLEXITY IN CHOICE OF INVESTMENT DECISIONS}

The Fundamental questions in all pension systems concern the choices made by individual. The most important issues are: whether and to what extent individuals should determine the choice of pension products provided; whether and to what extent individuals should determine the choice of investment portfolios; whether and to what extent individuals should determine the choice of stream of income in retirement. Consideration in this text focuses on individual retirement decisions that are made in the phase of capital accumulation. The subject of inquiry is questions about the causes: the reasons for the low interest of savings in the third pillar of pension provision in Poland; the causes in variation of savers determined by gender and age; the reasons for determining the allocation of assets within the Individual Retirement Account PZU (insurance company). For this purpose, the described facts are explained by referring to the reliable knowledge of behavioral economics. The author made the analysis of basic legal regulations governing the operation of individual retirement accounts, and individual retirement savings account, as well as the analysis of basic statistics describing the market. Attention is paid to the key growth barriers of the third pillar of pension provisions in Poland and savers investment behavior within the individual retirement accounts. The text concludes proposals aimed at encouraging the development of voluntary forms of pension provision in Poland.

Key words: investment decisions, pension systems, investment portfolios, income in retirement. 